\title{
Technological Innovation and Animal Law: Does Dignity Do the Trick?
}

\author{
Anne LANSINK*
}

\begin{abstract}
$E U$ and UK animal protection laws are underpinned by arguments based on the perceived desirability of reducing animal suffering. Technological innovations, however, give rise to ethically problematic situations in which suffering is not present or where it is not necessarily the only issue. Moreover, these developments further expose non-suffering related problems that were already present in existing areas of animal use. The existing animal protection laws are not capable of adequately addressing these problems. The concept of dignity might be a promising alternative. It is capable of covering situations other than those in which welfare is an issue, and using it might make the law more internally consistent.
\end{abstract}

\section{INTRODUCTION}

There is growing public concern for animals. This seems to have resulted from a better understanding of their capabilities and needs. ${ }^{1}$ We now know, for example, that (certain categories of) animals can feel pain, distress and fear, and that they can suffer lasting harm. ${ }^{2}$ Moreover, we are starting to appreciate "the social relationships which animals form", the "fact that many species mate for life" and "the fact that animals can die of grief". 3 The resultant public concern has led to the adoption of EU and UK animal protection laws. ${ }^{4}$ These laws focus on preventing unnecessary suffering.

At the same time, the world is witnessing a wave of technological innovations relating to issues such as cloning and genetic engineering. These are usually first tested on animals and are likely to be then applied to them on a larger scale (eg in the meat industry). This raises ethical questions, and therefore the more practical question of whether the existing foundations for and criteria used in animal laws are sufficient to deal

\footnotetext{
* DPhil Candidate, University of Oxford. I am very grateful to Charles Foster, Jonathan Herring, Imogen Goold, Richard Ashcroft, Menelaos Markakis, the anonymous reviewer(s), and the participants of a seminar organised in Oxford, a workshop organised in Leeds, and a conference held in Rotterdam for their feedback on earlier drafts. All remaining errors are my own.

1 Although see, for example, C Foster, "Pod Casts" (2018) 467 Literary Review, citing JM Colby, Orca: How We Came to Know and Love the Ocean's Greatest Predator (Oxford University Press 2018). Colby argues that the public concern about killer whales is a result of increased animal individuation.

2 Pavel Poc MEP, Directive 2010/63/EU Deb 8 September 2010. See also Mike Radford, Animal Welfare Law in Britain: Regulation and Responsibility (Oxford University Press 2001) 25-28.

3 Lord Melchett, HL Deb 28 November 1985, vol 468, col 1019.

4 ibid; Douglas Hurd MP, HC Deb 17 February 1986, vol 92, col 88.
} 
adequately with these developments. One concept that could prove useful in this context is the concept of dignity. This concept has a prominent position in the context of human rights and is often said to be their very basis. ${ }^{5}$ However, it has so far not been used to justify EU and UK animal laws. Would dignity do a better job than the criteria that are currently used, and what account of dignity could be a good candidate? These are the questions with which this paper is concerned.

The first part will give a short overview of the criteria that are currently used to justify EU and UK animal laws. It will be shown that these laws are underpinned by arguments based on the perceived desirability of reducing animal suffering. The second part will then examine whether such criteria are capable of dealing with the above-mentioned developments. It will be argued that this is not the case. More specifically, it will be argued that technological innovations affect animal ethics in two important ways. First, they create situations that were not previously imaginable, such as changing the very nature of an animal, thereby (physically) turning it into something that it is not. Second, they further expose problems underlying existing areas of animal use that are currently regulated based on mere suffering-based arguments. The third part therefore examines whether dignity would stand to do a better job. It will put forward the author's preferred account of dignity, which is Charles Foster's theory. The Swiss law on animals will be used to illustrate how such an account could be made more concrete. It will be argued that, in order to deal adequately with the challenges flowing from technological innovations, a shift of emphasis from animal welfare to animal dignity is required. Notably, the use of dignity might make the law more internally consistent, and dignity also covers situations other than those where welfare is an issue.

\section{Current foundations of EU And UK Animal laws}

EU and UK animal laws are based on the fact that animals are sentient beings. These are beings that are "capable of feeling pleasure and pain" 6 or "capable of experiencing pain and suffering". 7 The EU's main basis of animal protection can be found in Art 13 of the Treaty on the Functioning of the European Union (TFEU). This article reads as follows:

"In formulating and implementing the Union's agriculture, fisheries, transport, internal market, research and technological development and space policies, the Union and the Member States shall, since animals are sentient beings, pay full regard to the welfare

5 See Section IV.

6 European Commission, "EU Animal Welfare Strategy 2012-2015" < ec.europa.eu/food/sites/food/files/animals/ docs/aw_brochure_strategy_en.pdf > accessed 15 March 2019, 1. It was not immediately clear what meaning the EU would give to sentience. It was initially thought that it was equated with the capacity for feeling pain. Later on, the Commission removed this uncertainty by stating that "sentient beings are beings that are capable of feeling pleasure and pain”. See T Kelch and R Buckley, Globalization and Animal Law: Comparative Law, International Law and International Trade (Kluwer Law International 2011) 86.

7 Explanatory Notes to the UK Animal Welfare Act 2006, para 12. See also AWA, s 1(4). The Notes, however, do not form part of the Act and have not been endorsed by Parliament. In fact, it is currently under dispute how sentience should be defined, if at all. A recent written ministerial statement equated it to "pain and pleasure". Mike Radford even suggested defining "animal" in more concrete terms instead, taking New Zealand's Animal Welfare Act 1999 as an appropriate model, thereby taking away the need to define sentience. See Secretary of State for Environment, Food and Rural Affairs, Animal Welfare (Sentencing and Recognition of Sentience) Draft Bill (Cmd 9554, 2017) (Draft Bill); Department for Environment, Food and Rural Affairs, Animal Welfare (Sentencing and Recognition of Sentience) Draft Bill: Consultation Response (August 2018); Written evidence submitted by Mike Radford (AWB0014). 
requirements of animals, while respecting the legislative or administrative provisions and customs of the Member States relating in particular to religious rites, cultural traditions and regional heritage".

The recognition of sentient beings, which is central to this provision, was not part of the original article, but was added by the Treaty of Lisbon. ${ }^{8}$ This addition officially elevated animals' legal status from mere "tradable products" to sentient beings. To be sure, there was already some EU legislation relating to animal welfare before this. However, "welfare was largely seen as an intrinsic part of the agricultural production system; if an animal could grow in line with expected productivity levels, then its welfare was not in question". 10 Thus, animal welfare was looked at from a commercial point of view. It should be noted, however, that it is disputed in the literature whether the official recognition of sentient beings has actually improved animal welfare substantially, beyond its symbolic value. ${ }^{11}$

Regarding the UK, the recognition of sentient beings mainly follows from its principal animal welfare legislation, the Animal Welfare Act 2006 (AWA). AWA applies only to "vertebrates other than man", ${ }^{12}$ because, according to the Explanatory Notes to the Act, these are "currently the only demonstrably sentient animals". ${ }^{13}$ According to the Notes, AWA could be extended to cover invertebrates in the future if the appropriate national authority was "satisfied on the basis of scientific evidence that these too [were] capable of experiencing pain or suffering". ${ }^{14}$ There is, however, abundant evidence that some invertebrates are sentient. ${ }^{15}$ Accordingly, AWA is misconceived. Indeed, for this reason the Animals Scientific Procedures Act 1986 also protects living cephalods. ${ }^{16}$ AWA might, however, be corrected in this respect in the near future. On 12 December 2017, the Government published a Draft Bill that intends explicitly to recognise animal sentience in domestic law after Brexit. ${ }^{17}$ In response to this, it has received "scientific evidence covering the status of organisms such as octopus and cephalopods". ${ }^{18}$ Nevertheless, the salient point for present purposes is that it is clear that the UK legislature lays the basis of animal protection in their sentience.

\footnotetext{
8 Treaty of Lisbon [2007] OJ C306/1, entered into force on 1 December 2009. The recognition of sentient beings had, however, already been present in the Protocol to the EC Treaty on the Protection and Welfare of Animals. See European Commission, Health \& Consumer Protection, Directorate-General, "Animal Welfare Factsheet" (March 2007) < ec. europa.eu/food/animals/docs/aw_efsa_opinions_factsheet_farmed03-2007_en.pdf > accessed 15 March 2019.

9 Art 38 EEC.

10 K Sowery, "Sentient Beings and Tradable Products: The Curious Constitutional Status of Animals under Union Law" (2018) 55 Common Market Law Review 55, 60-65.

11 ibid, 82-85.

12 AWA, s 1(1).

13 Explanatory Notes to AWA, para 12.

14 ibid; AWA, s 1(4).

15 See, for example, H Proctor, “Animal Sentience: Where are We and Where are We Heading?” (2012) 2(4) Animals 628. This issue has also been discussed in Parliamentary debates: Animal Welfare Bill Deb 17 January 2006, cols 6-7, 8; Pavel Poc, Directive 2010/63/EU Deb 8 September 2010.

16 See written question (nr 221976) asked by Kerry McCarthy on 26 January 2015, answered on 29 January 2015, < publications.parliament.uk/pa/cm201415/cmordbk2/150129o01.htm > accessed 15 March 2019, in combination with Directive 2010/63/EU of the European Parliament and of the Council of 22 September 2010 on the protection of animals used for scientific purposes [2010] OJ L276/33, recital 8.

17 Draft Bill, supra, note 7. One of its two main purposes was to ensure that animals will "not lose any recognition or protections once the UK leaves the EU”. See the Explanatory Notes to the Draft Bill, paras 2 and 5.

18 Environment, Food and Rural Affairs Committee, Pre-Legislative Scrutiny of the draft Animal Welfare (Sentencing and Recognition of Sentience) Bill 2017: Government Response to the Committee's Second Report (HC 984, 23 April 2018) 4. See also, for example, Radford, supra, note 7,7, who has submitted that, in addition to cephalopods, there is a
} 
In terms of substantive protection, the law seems to protect the so-called "Five Freedoms". ${ }^{19}$ This concept originates from the Brambell Report ${ }^{20}$ and has allegedly become a "worldwide standard". 21 Although the jurisdictions examined in this contribution use different formulations of the Five Freedoms, their content is very similar. The EU aims to protect animals from hunger and thirst; discomfort; pain, injury and disease; fear and distress; and it wants animals to "express normal behaviour". In order to express such behaviour, animals should have "adequate space and facilities" and "company of [their] own kind". 22 The UK law uses a positive formulation. It aims to provide animals with a "suitable environment" and a "suitable diet", and it wants animals to be "housed with, or apart from, other animals" and to "exhibit normal behaviour patterns". Additionally, it aims to protect them from "pain, suffering, injury and disease". ${ }^{23}$ The use of the adjective "suitable" is interesting, as it acknowledges that what might be suitable for one animal might not be suitable for another. Thus, the legislature seems to acknowledge that different animals have different needs. The Five Freedoms are visible throughout both legal frameworks. ${ }^{24}$

The Five Freedoms have been criticised for "neglect[ing] some of the key scientific elements [of animal welfare]. In particular, [they] neglect to cover the species-specific behavioural needs of animals in any comprehensive manner". ${ }^{25}$ Arguably, providing animals with, among other things, "sufficient space and proper facilities" does not necessarily guarantee that the animal can express "normal behaviour". It has therefore been proposed to expand the Five Freedoms, thereby focusing on "the state of the animal - how the animal might experience its life - rather than the mere nature and quality of its living conditions, which may be assessed through the provision of certain resources". ${ }^{26}$ It should, however, be noted that, even if such proposals were to be implemented, the laws would still merely focus on animal suffering (and on pleasure, for that matter). They would not go beyond the animal's own experience. Bart Driessen, for his part, suggests adding a sixth freedom: the "freedom from being killed for unnatural reasons". 27 Although I support this approach of looking beyond the animal's subjective experience, I argue that there is still some more substantive ground to cover. ${ }^{28}$

\footnotetext{
(F'note continued)

"growing scientific consensus that at least some molluscs and crustaceans are sentient". He also advised to consider looking more into whether any animals in their embryonic or foetal form should be included.

19 See A Lansink, "The Use of Dignity in EU and UK Animal Protection Laws" (MPhil thesis, University of Oxford 2017) 47-50. It should, however, be noted that only a limited category of animals enjoys the protection of these freedoms. Broadly speaking, they apply only to animals for whom someone is responsible. Cruelty offences laid down in UK law, in contrast, have a wider application.

20 Minister of Agriculture, Fisheries and Food and the Secretary of State for Scotland, Report of the Technical Committee to Enquire into the Welfare of Animals kept under Intensive Livestock Husbandry Systems (Cmd 2836, 1965).

21 A Peters, "Liberté, Égalité, Animalité: Human-Animal Comparisons in Law" (2016) 5 Transnational Environmental Law 25, 34.

22 "Animal Welfare Factsheet", supra, note 8.

23 See, eg, British Veterinary Association, “Animal Welfare” < www.bva.co.uk/News-campaigns-and-policy/Policy/ Ethics-and-welfare/Animal-welfare/ > accessed 15 March 2019; AWA, s 9.

24 Lansink, supra, note 19, 49-50.

25 Sowery, supra, note $10,78$.

26 ibid.

27 B Driessen, "Fundamental Animal Rights in European Law" (2017) 23 European Public Law 547, 576-578.

28 As discussed in section III.
} 
The concept of dignity does not currently play any substantive role in the justification of EU and UK animal laws. ${ }^{29}$ The word dignity does not appear in the text of these laws and they do not need this concept for their further explanation. Despite this, there is some lay use of the word "dignity" in the parliamentary debates. However, it seems that when legislators are talking about animal dignity, they merely mean to say that animals have worth as well as the humans whom it is assumed have dignity. That they too count as individuals. Furthermore, legislators acknowledge the impact of animal abuse on human dignity. ${ }^{30}$ However, they do not use the concept of dignity for animals themselves. Their goal is only to prevent unnecessary suffering in animals.

The UK has a more extensive legal framework regarding animal protection than the EU. For example, there is no EU legislation with respect to animals in circuses, pets or strays. ${ }^{31}$ This difference can be readily explained by the nature of the respective legal systems. The UK Parliament is in principle able to legislate on any issue it desires. The EU, however, only has limited competence and is bound by the principles of conferral, subsidiarity and proportionality. ${ }^{32}$ I argue that the principle of conferral is crucial, as the powers conferred on the EU in relation to animals are limited. First, Art 13 TFEU shows us that the EU's powers are linked to animal sentience. Second, the EU can only take into account animal welfare requirements when developing policies in certain areas - ie those mentioned in the aforementioned article. It is thus not empowered to create any self-standing policies on this topic. ${ }^{33}$ Besides the principle of conferral, the subsidiarity principle is also very important. Individual countries (or even sub-national entities, such as regions) might be better able to make provisions for certain areas of animal protection. The European Commission has, for example, stated that the welfare of circus animals is a matter for the Member States. ${ }^{34}$ Generally, it seems that the EU prefers individual countries to take measures regarding animal welfare, or at least them taking the initiative to do so. ${ }^{35}$ This approach could also be explained by the EU's main function. It is not primarily concerned with animal welfare, but rather with the establishment and functioning of the internal market. ${ }^{36}$ Yet another factor to which the limited amount of EU animal protection legislation can be ascribed is Art 13 TFEU's requirement to take into account the "religious rites, cultural traditions and regional heritage" of the Member States. Katy Sowery notes that there are "obvious disparities in the views of the Northern, Southern, and Central and Eastern European countries on

\footnotetext{
29 Lansink, supra, note 19.

30 Eg in the context of zoos or animal testing.

31 As regards stray animals, this seems to be confirmed by European Parliament Resolution of 4 July 2012 on the establishment of an EU legal framework for the protection of pets and stray animals 2012/2670 (RSP). Moreover, in its animal welfare policy paper for 2010-2015, the UK government confirmed that there was no EU legislation on the welfare of animals in circuses or the welfare of pets: <www.gov.uk/government/publications/2010-to-2015government-policy-animal-welfare/2010-to-2015-government-policy-animal-welfare > accessed 15 March 2019.

32 See Art 5(2), (3) and (4) TEU.

33 Animal protection may, however, also be pursued through means such as Union environmental policy (Art 191 TFEU) or other harmonisation measures (based on Art 114 TFEU), although the purpose of these is not to protect the welfare of individual animals.

34 Environment, Food, and Rural Affairs Committee, Wild Animals in Circuses (fourth report) (HC 2013-14, 553-I).

35 See Caroline Lucas MEP, HC Deb 23 June 2011, vol 530, cols 565-66.

36 On the EU's internal market and animal protection laws see generally Sowery, supra, note 10.
} 
animal welfare". ${ }^{37}$ This further complicates things when it comes to reaching an agreement on proposed legislation.

\section{ARE THESE CRITERIA SUFFICIENT TO DEAL WITH TECHNOLOGICAL DEVELOPMENTS?}

We have seen that the EU and UK animal laws aim to prevent unnecessary suffering to animals. Animals are protected because they are, and to the extent that they are, sentient. The criteria used by the law are in line with this. The question arises whether these criteria are sufficient to deal with all undesirable situations of animal use and being that we are currently facing, or that we risk facing. In what follows, I will argue that they are not. There are situations in which suffering is not prevalent (or not necessarily the only problem), but which might still be ethically wrong and therefore undesirable. Technological innovations give rise to many such problems.

Animals have already been genetically modified in various ways. Examples abound in this respect. Researchers have engineered "swine that pollute less, fend off disease, and produce more meat", ${ }^{38}$ hornless dairy calves, ${ }^{39}$ TB-resistant cows, ${ }^{40}$ and fast-growing salmon. ${ }^{41}$ Other recent innovations include beagles that are more muscular, which "are expected to have stronger running ability, which is good for hunting, police (military) applications", 42 and silkworms that create fluorescent silks for fashion purposes. ${ }^{43}$ Additionally, there are fluorescent animals, ${ }^{44}$ micro pigs ${ }^{45}$ and silk-spinning goats. ${ }^{46}$ Experiments relating to cloning and xenotransplantation have also been taking place. The genes of pigs are being adjusted in order to be able to provide organs for human

37 ibid, 87-88.

38 K Grens, "The Superpowers of Genetically Modified Pigs" (The Scientist, 1 August 2018) <www.the-scientist. com/notebook/the-superpowers-of-genetically-modified-pigs-64513 > accessed 15 March 2019.

39 DF Carlson et al, "Production of Hornless Dairy Cattle from Genome-Edited Cell Lines" (2016) 34 Nature Biotechnology 479; J Akst, "Genetically Engineered Hornless Dairy Calves" (The Scientist, 10 May 2016) < www.thescientist.com/the-nutshell/genetically-engineered-hornless-dairy-calves-33553 > accessed 15 March 2019.

40 H Wu et al, "TALE Nickase-Mediated SP110 Knockin Endows Cattle With Increased Resistance to Tuberculosis" (2015) 112 (13) PNAS 1530-1539; J Rood, "Engineering TB-Resistant Cows" (The Scientist, 3 March 2015) < www. the-scientist.com/the-nutshell/engineering-tb-resistant-cows-35837 > accessed 15 March 2019.

41 This is called the AquAdvantage ${ }^{\mathrm{TM}}$ Atlantic Salmon and has been allowed on the market of some countries already: A Olena, "GM Salmon Goes Commercial" (The Scientist, 26 November 2013) < www.the-scientist.com/the-nutshell/ gm-salmon-goes-commercial-38356> accessed 15 March 2019; A Pollack, "Genetically Engineered Salmon Approved for Consumption" (The New York Times, 19 November 2015) < www.nytimes.com/2015/11/20/business/ genetically-engineered-salmon-approved-for-consumption.html > accessed 15 March 2019.

42 J Akst, "Genetically Engineered Dogs" (The Scientist, 21 October 2015) < www.the-scientist.com/the-nutshell/ genetically-engineered-dogs-34636> accessed 15 March 2019.

43 K Yandell, "Genetically Modified Fashion" (The Scientist, 20 June 2013) < www.the-scientist.com/the-nutshell/ genetically-modified-fashion-39148 > accessed 15 March 2019. Such might also be applied in a medical context: T Lizuka et al, "Colored Fluorescent Silk Made by Transgenic Silkworms" (2013) 23 Advanced Functional Materials 5232.

44 Like ANDi the rhesus monkey and Alba the rabbit. See J Savulescu, "Genetically Modified Animals: Should There Be Limits to Engineering the Animal Kingdom?" in TL Beauchamp and RG Frey (eds), The Oxford Handbook of Animal Ethics (Oxford University Press 2011) 641, 643.

45 D Cyranoski, "Gene-Edited 'Micropigs' to be Sold as Pets at Chinese Institute” (2015) 526 Nature 18.

46 T Lewis, "10 Times Scientists Genetically Modified Animals and Came Up with Some Weird Results" (Business Insider, 17 October 2015) <www.businessinsider.com/genetically-modified-animal-experiments-2015-10? international=true \&r=US\&IR=T\#dolly-the-sheep-1 > accessed 15 March 2019. 
bodies. ${ }^{47}$ These innovations are likely to be used in different contexts: for example in the context of farming, research, health care, fashion, pets and service animals. Relatedly, they serve a variety of purposes, such as commercial purposes, the preservation of endangered species, and the protection of human health, the environment, the public and individual animal welfare. ${ }^{48}$

There might sometimes be suffering involved in these situations, for example because of flawed technical procedures or side-effects. ${ }^{49}$ These issues could perhaps be solved by further perfecting the procedure in question or by further modifying the animal genetically. However, it could also be the case that pain is not present, or that the procedure in question even serves to reduce the amount of pain experienced by animals (for example, in the case of hornless calves). Those who focus only on reducing the amount of suffering might therefore support such innovations. Indeed, the technological developments mentioned above sometimes serve a noteworthy cause, and the immense suffering caused to animals is definitely one of the most prominent problems in some industries (such as the meat, leather, egg, or dairy industries). Being able to reduce their suffering would therefore seem like a great step forward. However, others might feel less ethically comfortable with such innovations. Even though suffering might not be present (or even reduced), many might still feel that we are doing something that is morally wrong. Not only because of the affront to human dignity (which could persuasively be argued for in such cases), ${ }^{50}$ but most of all because the animals are wronged in their own right as well. They are denied the opportunity to be the being that they actually are, and instead transformed into something that they are not, often in order to be used as an object by human beings.

This ethical element - that of transforming the animal into something that it is not seems to be present in most cases of animal biotechnology, regardless of whether the animals concerned are suffering or not. However, from a legal standpoint the presence or absence of suffering is clearly relevant. In this connection, we can distinguish between three different situations. First, there are cases where the alteration to the animal causes it to suffer (for example because of flawed procedures or side-effects). Although it could be argued that the justifications underlying the laws are incomplete because they ignore the alteration of the animal as such, the criteria used in animal laws can generally address

\footnotetext{
47 C Zimmer, "Editing of Pig DNA May Lead to More Organs for People" (The New York Times, 15 October 2015) <www.nytimes.com/2015/10/20/science/editing-of-pig-dna-may-lead-to-more-organs-for-people.html? action $=$ click\&module $=$ RelatedCoverage \&pgtype=Article\&region=Footer $>$ accessed 15 March 2019.

48 For some more (possible) applications, see also A Charo and H Greely, "CRISPR Critters and CRISPR Cracks" (2015) 15 The American Journal of Bioethics 11.

49 For some examples, see E Ormandy et al, "Genetic Engineering of Animals: Ethical Issues, Including Welfare Concerns" (2011) 52 The Canadian Veterinary Journal 544, 547-548. Veterinarian Michael Fox is also concerned about the suffering that genetic engineering might cause to animals: L Munro, "Future Animal: Environmental and Animal Welfare Perspectives on the Genetic Engineering of Animals" (2001) 10 Cambridge Quarterly of Healthcare Ethics 314, 320 .

50 T Warkentin, "Dis/Integrating Animals: Ethical Dimensions of the Genetic Engineering of Animals for Human Consumption" in SJ Armstrong and RG Botzler (eds), The Animal Ethics Reader (Taylor \& Francis 2017) 434, 443-445 for example points out how such developments could affect our own humanity. Generally speaking, the concept of Janus-faced dignity has been discussed by various authors. See for example Mountfield and Singh, cited in Baroness Hale, "Dignity" (2009) 31 Journal of Social Welfare and Family Law 101, 106; M Rosen, Dignity: Its History and Meaning (Harvard University Press 2012) 157. We will see in Section IV that Charles Foster argues for an even broader concept of dignity by focusing on the dignity interests of all stakeholders.
} 
such situations, as they aim to prevent (unnecessary) suffering. Second, there are cases where the technological development concerned does not cause any extra suffering or even reduces the amount of suffering, but where the overall practice for which the animal is used is still detrimental to the animal's welfare. This could, for example, be the case as far as hornless calves are concerned. Removing their horns spares them the pain of being dehorned, but the practice of farming might nevertheless contain many other elements that would cause the calf to suffer. It is noteworthy, however, that one could not use suffering arguments in such cases to combat the specific technological innovation, unless the innovation prevents the industry from improving any further or from being eliminated altogether (because the industry leaders decide, for example, to solve some of the more severe suffering problems through genetic engineering, as a result of which public concern and political priorities would shift away). ${ }^{51}$ One could, however, still use suffering-based arguments to combat the practice as a whole. Indeed, one would then not be opposing the technological innovation as such, but the elimination of the overall practice would (in many cases) lead to the elimination of the specific type of genetically modified animals as well.

The third type of case seems to be the most problematic one from a legal point of view. This is the case where neither the innovation nor the overall practice causes any suffering (or even reduces it). A practice or industry may, for example, not cause any suffering due to its nature. This may be the case where pets are involved. Innovations one could think about in this context are micropigs and fluorescent animals. ${ }^{52}$ A second reason why an overall practice might not cause any suffering can be found in the practice of genetically removing the animal's ability to suffer altogether. ${ }^{53}$ This seems to be the most extreme situation and it is not just hypothetical. In 2004, scientists affiliated with University College London created mice which were "much less vulnerable to pain both from external stimuli and from inflammation-induced sensitivity", even though "their ability to experience normal variations in heat and pressure was unchanged". ${ }^{44}$ Researchers also managed to create mice with "bodies that were normally formed except for lacking heads". 55 This "vividly raise[s] the possibility that highly social and intelligent animals, such as pigs, which suffer greatly in current factory farming conditions, could be engineered or bred to have just enough brain stem to support biological growth, but not enough to support consciousness". 56 In such case there is virtually nothing left of the

51 See also P Sandøe et al, "The Blind Hens' Challenge: Does it Undermine the View that Only Welfare Matters in Our Dealings With Animals?” (2014) 23 Environmental Values 727, 732.

52 This argument, of course, only holds true if the other conditions, such as the living circumstances of the pet, are not detrimental to the animal's welfare and if the fluorescent being for instance does not suffer from any other relevant sideeffects such as being more prone to being found or caught by predators.

53 See also SE Gavrell Ortiz, "Beyond Welfare: Animal Integrity, Animal Dignity, and Genetic Engineering" (2004) 9 Ethics and the Environment 94 for a discussion on how various theories approach this issue, concluding that dignity is the only concept that succeeds in plausibly explaining why such a situation is ethically wrong.

54 Savulescu, supra, note 44, 649, citing MA Nassar et al, "Nociceptor-Specific Gene Deletion Reveals a Major Role for Nav1.7 (PN1) in Acute and Inflammatory Pain" (2004) 101 Proceedings of the National Academy of Sciences of the United States of America 12706-11.

55 R Streiffer and J Basl, "Ethical Issues in the Application of Biotechnology to Animals in Agriculture" in Beauchamp and Frey, supra, note 44, 826, 838, citing W Balduini et al, "Microencephalic Rats as a Model for Cognitive Disorders" (1986) 9 Clinical Neuropharmacology s8-18 and I Bach, "The LIM Domain: Regulation by Association" (2000) 91 Mechanisms of Development 5-17.

56 ibid. 
animal itself, apart from its (heavily modified) body. Mere suffering-based criteria cannot help addressing the arguable wrongness of the situation. ${ }^{57}$

The problems that occur in the situations adumbrated above are not just hypothetical or only present in the (distant) future. Nor are they strictly limited to cases of genetic manipulation and cloning. There are already various areas of animal use or practices that may reveal problems that go beyond suffering (or where suffering might not be the most prominent problem), such as circuses, zoos, bestiality, and animal pornography: chimpanzees having tea parties; elephants standing on their heads or rolling on a barrel; dancing and hula hooping bears; tigers running in hamster wheels; and elephants positioned on stools in a sort of polonaise position, many of the times even dressed up in human clothes. In the case of bestiality and animal pornography animals are (at least in some circumstances) used as mere sexual objects. And what to think about the countless YouTube videos of performing animals $?^{58}$ Or about the various animal parades that are held all over the world, such as the Manchester Spooky Pooch Parade, where dogs parade in the most extravagant costumes? A similar example concerns the introduction of penguins on a London ice rink for entertainment purposes. ${ }^{59}$ Furthermore, one could think about dead animals that are displayed in peoples' homes for decoration purposes and about rabbits that are skinned on Facebook via livestream. ${ }^{60}$ The areas mentioned are currently either regulated based on animal suffering ${ }^{61}$ or on the basis of non-animal related arguments (such as human dignity), ${ }^{62}$ or not regulated at all. To be sure, some of these practices are more controversial than others. Admittedly, it is hard to draw the line between those practices that are ethically acceptable and those that are not - not least because of "the importance of context" and the great variety of animal species (and their differing nature, needs, and capacities). ${ }^{63}$ The salient point for present purposes is that EU and UK animal laws do not yet have the tools to (adequately) address such practices. $^{64}$

Thus, ethical problems that go beyond mere suffering (and that were not caused by technological innovations) already exist. The effects of the innovations are therefore twofold. Not only do they create situations that were previously not imaginable, such as changing the very nature of an animal, thereby physically turning it into something that it is not. They also serve to further expose the problems that are already present in existing

\footnotetext{
57 It should, however, be acknowledged that the fact that (the criteria laid down in) animal protection laws cannot address these practices does not mean that they could not be addressed by other laws (eg laws on food safety, the protection of public health, environmental protection laws, and so on).

58 I am grateful to Professor Jonathan Herring for this suggestion.

59 L Thomson, "Londoners Will Soon Be Able to Ice Skate with Real Penguins at Queens Skate Dine Bowl” (Evening Standard GO London, 10 January 2019) <www.standard.co.uk/go/london/attractions/ice-skating-penguins-queensice-rink-london-a4035776.html > accessed 15 March 2019. I am grateful to Professor Charles Foster for bringing this to my attention.

$60 \mathrm{AD}$, "Slager onder vuur vanwege live villen konijn op facebook" (AD, 13 May 2017) < www.rtlnieuws.nl/ nederland/slager-onder-vuur-vanwege-live-villen-konijn-op-facebook > accessed 15 March 2019; M Wouters, "Villen van konijn live op Facebook, is dat oké?" (Metro Nieuws, May 2017) <www.metronieuws.nl/in-het-nieuws/hetgesprek/2017/05/villen-van-konijn-live-op-facebook-is-dat-oke > accessed 15 March 2019.

61 In the case of circuses and zoos. See Lansink, supra, note 19, 84-88.

62 ibid, 83-84: in the case of bestiality.

63 RE Loder, "Animal Dignity” (2016) 23 Animal Law 1, 4-5, 30, 37.

64 Although I accept that some of these practices could be addressed, were the legislators to use a broader notion of natural behaviour.
} 
areas of animal use. If we are able to take away animal suffering in areas such as circuses and zoos, we are forced to look deeper into them, facing some seemingly unethical practices. The criteria used by the law, then, turn out to fall awkwardly short. Thus, in order to address those situations that many might feel ethically uncomfortable with, but in which no animal suffering is prevalent and the affront to human dignity is not the only problem, another concept seems to be needed, perhaps more than ever before: dignity.

\section{A GOOD CANDIDATE: DIGNITY}

Dignity already plays a prominent role in the field of human rights. ${ }^{65}$ This is especially true for the EU. Article 2 TEU states that human dignity is one of the founding values of the EU. Furthermore, it is mentioned in the preamble to the EU Charter of Fundamental Rights and enshrined in Title I of the Charter. The European Court of Human Rights, too, has stated on various occasions that the "very essence" of the European Convention on Human Rights (ECHR), of which the Human Rights Act 1998 is a direct implementation, is "respect for human dignity and human freedom". ${ }^{6}$ Using dignity to justify EU and UK animal laws might therefore make the law more internally consistent. $^{67}$

But what account of dignity would be most suitable? For reasons I cannot fully set out here due to space constraints, ${ }^{68}$ I prefer the one developed by Charles Foster. ${ }^{69}$ He says that dignity is objective flourishing. ${ }^{70}$ It is about being the type of being that you are. Foster admits that he does not know what objective thriving precisely consists of. Controversially, he argues that it is an empirical question and therefore best answered by, say, anthropologists, rather than lawyers. He does, however, help us a bit further by bringing forward two elements that are important in relation to human thriving and, so I

\footnotetext{
65 For an accurate overview, see McCrudden, "Human Dignity and Judicial Interpretation of Human Rights" (2008) 19 The European Journal of International Law 544 and C Dupré, The Age of Dignity (Hart 2015).

66 Christine Goodwin v UK (2002) 35 EHRR 18, para 90; SWv UK (1996) 21 EHRR 363, para 44; Pretty v UK (2002) 35 EHRR 1, para 65; Bouyid v Belgium (2016) 62 EHRR 32, para 89. For an overview of the ECtHR's use of dignity, see J-P Costa, "Human Dignity in the Jurisprudence of the European Court of Human Rights" in C McCrudden (ed), Understanding Human Dignity (Oxford University Press 2013) 393.

67 This claim is, however, only of relative validity, as it is predicated on the assumption that human dignity and animal dignity, as used in the law, function in the same way (which is, for instance, not the case in Swiss animal protection law). Furthermore, insofar as dignity is strongly connected with fundamental rights in human rights law, the question arises as to whether consistency would require animals to have rights as well were animal dignity to be introduced in the law.

68 These reasons are, however, set out in A Lansink, "The Desirability and Consequences of Using Dignity in EU and UK Animal Protection Laws" (DPhil thesis, University of Oxford, ongoing).

69 C Foster, Human Dignity in Bioethics and Law (Hart 2011). Other theories one could think about are those of Kant, Killmister, Nussbaum, and divine dignity. See T Hill, "Kantian Perspective on the Rational Basis of Human Dignity" in M Düwell et al (eds), The Cambridge Handbook of Human Dignity: Interdisciplinary Perspectives (Cambridge University Press 2014) 215-21; S Kersten, "Kantian Dignity: A Critique" in Düwell et al, supra, note 69, 222; O Sensen, "Kant's Conception of Human Dignity" (2009) 100 Kant-Studien 309; S Killmister, "Dignity: Not Such a Useless Concept" (2010) 36 Journal of Medical Ethics 160; J Soskice, "Human Dignity and the Image of God" in McCrudden, supra, note 66, 229; D Gushee, "A Christian Theological Account of Human Worth" in McCrudden, supra, note 66, 278; M Nussbaum, "Beyond 'Compassion and Humanity': Justice for Nonhuman Animals" in C Sunstein and M Nussbaum (eds), Animal Rights: Current Debates and New Directions (Oxford University Press 2006) 299. On Nussbaum's dignity theory more generally, see M Nussbaum, "Beyond the Social Contract: Toward Global Justice" (The Tanner Lectures on Human Values, Australian National University, 12-13 November 2002, and University of Cambridge, 5-6 March 2003).

70 Foster, supra, note 69, 6.
} 
argue, also for the thriving of many animal species. First, human beings are "not human ["animal"] in a vacuum". They are embodied animals who "exist in a social, political and physical environment". "What happens to the bodies of humans affects all elements of them". 71 Second, "humans don't do well by themselves. At bottom they are social animals. Not only do they smile more, but they do more and do better when they are part of a community. That means that the most accurate description of an individual will be in terms of the nexus of relationships in which she exists". ${ }^{72}$

Thus, dignity is about being the type of being that you are. A being consists of at least two elements: it is a member of its species, but beyond this, also a unique individual. ${ }^{73}$ Other elements that might perhaps be considered constitutive of a being are family and group or community membership. ${ }^{74}$ For the purposes of this article, I will mostly focus on the first element: that of species membership. The importance of it has been recognised by various other authors. ${ }^{75}$ But how could the appropriate treatment flowing from it be explained in more concrete terms? An example of how this could be done is given by Swiss law. Interestingly, Swiss law incorporated the concept of animal dignity precisely because of the threat posed by technological developments.

Before proceeding to examine the Swiss animal laws in some more detail, it is worth noting that they have been influenced in their interpretation by the inherent value theory designed by Balzer, Rippe, and Schaber. ${ }^{76}$ The authors claim that non-human animals have dignity mostly because they have "a good of their own". 77 This means that "[t]hings can happen and be done to them which are good or bad for them". ${ }^{78}$ It can be understood in a subjectivist and an objectivist way. ${ }^{79}$ The first view links dignity to sentient beings, whereas the second one links it to all living beings. I agree with Schaber that only the objective view could help us further, as it is only this view that goes beyond subjective experiences. ${ }^{80}$ How should those with dignity be treated then? They should be taken into account "for their own sake". ${ }^{81}$ The Swiss law may also have been influenced by other reports. ${ }^{82}$

71 ibid, 12.

72 ibid.

73 See also Foster, supra, note 69, 6. On human thriving and the (English) law, see further C Foster and J Herring, Human Thriving and the Law (Springer 2018).

74 Although there could be said to be some overlap between these various categories.

75 See, for example, S Laba Cataldi, "Animals and The Concept of Dignity: Critical Reflections on a Circus Performance" (2002) 7 Ethics \& The Environment 104; R Preece and L Chamberlain, Animal Welfare and Human Values (Wilfrid Laurier University Press 1993) 205-206.

76 The authors provided the Swiss Government with an expert report on animal dignity: P Balzer et al, Was heisst Würde der Kreatur?: Expertenbericht (Bundesamt für Umwelt, Wald und Landschaft 1997). For the English version, see P Balzer et al, "Two Concepts of Dignity for Humans and Non-Human Organisms in the Context of Genetic Engineering" (2000) 13 Journal of Agricultural and Environmental Ethics 7. See also G Bolliger, "Legal Protection of Animal Dignity in Switzerland: Status Quo and Future Perspective" (2016) 22 Animal Law 311, 338-343.

77 R Heeger, "Dignity, Only for Humans? A Controversy" in Düwell et al, supra, note 69, 541, 543.

78 P Schaber, "Dignity Only for Humans? On the Dignity and Inherent Value of Non-Human Beings" in Düwell et al, supra, note $69,547$.

79 ibid, 547-548.

80 ibid. In this context, Schaber has mentioned the use of "drugs or breeding techniques to make sure that, for instance, pigs could tolerate extremely restrictive living conditions without experiencing it as bad".

81 ibid, 547.

82 Such as I Praetorius and P Saladin, Die Würde der Kreatur: (Art. 24novies Abs. 3 BV) (Bundesamt für Umwelt, Wald und Landschaft 1996); GM Teutsch et al, Die "Würde der Kreatur": Erläuterungen zu einem neuen Verfassungsbegriff am Beispiel des Tieres (Haupt 1995). 
As regards the content of those provisions, Art 120(2) of the Federal Constitution ${ }^{83}$ and Art 1 of the general federal animal-protection law, the TSchG, ${ }^{84}$ protect the dignity of animals. The latter is defined as the inherent worth or value of the animal that must be respected. ${ }^{85}$ The relevant state authority, the Federal Food Safety and Veterinary Office (FSVO), has stated that inherent good means that "it is appropriate for an individual living being to be able to lead a life typical of its species". ${ }^{86}$

The Swiss law elaborates on the meaning of this sentence in Art 3 TSchG. It states that animal dignity is violated when a strain imposed on the animal cannot be justified by overriding interests. Strains are, in particular: pain; suffering; harm; anxiety; humiliation; major interference with an animal's appearance; major interference with an animal's abilities; and excessive instrumentalisation. ${ }^{87}$ Some of these strains merit further explanation. Harm is understood as an "[i]mpairment of species-specific properties, functions and habits", 88 especially "impairment of growth, reproductive capacity, adaptive capacity, mobility, and species-specific social behaviours". This includes the criterion of "major interference with the abilities". A major interference with the appearance is caused if: (a) "the change leads to a loss of function"; and (b) it is "permanent or irreversible", such as tail or ear docking. Coat trimming in a poodle does not fall in this category. An animal is humiliated if it is "perceived and treated in a way that completely disregards its moral status as a living being that should be respected for its own sake". Consciousness of the animal is not required. Humiliation is caused by: (a) "mechanisation of the animal"; (b) "making fun of the animal"; (c) "portrayal of the animal as inanimate, objectification"; (d) "measures associated with a complete loss of control (cyborg)". Excessive instrumentalisation occurs when an animal's inherent good is "completely disregarded". 89

The definition adopted by Swiss law covers a very broad range of elements that are visible in other dignity theories. It covers elements such as pain and suffering, which is reminiscent of the utilitarian "dignity" theory, ${ }^{90}$ but also excessive instrumentalisation, which hints at Kant's theory. It further adds some unique elements to the main dignity theories: the major interference with an animal's appearance; the major interference with an animal's abilities; and humiliation defined in an objective way (and not just in a subjective manner, therefore consciousness is not required). It is exactly these three criteria (together with the excessive instrumentalisation criterion) that appear to be both accurate and helpful whenever acts (negatively) affect animals (or human beings) without them being conscious.

\footnotetext{
83 Bundesverfassung [BV] [Constitution] Apr. 18, 1999, SR 101 (Switz). See Bolliger, supra, note 76, 323. Art 120 concerns the use of reproductive and genetic material.

84 Tierschutzgesetz (SR 455 Animal Welfare Act of 16 December 2005).

85 Art 3(a) TSchG. See M Michel and E Schneider Kayasseh, "The Legal Situation of Animals in Switzerland: Two Steps Forward, One Step Back - Many Steps To Go" (2011) 7 Journal of Animal Law 1, 14.

86 Federal Food Safety and Veterinary Office (FSVO), "Dignity of the Animal: Explanatory Notes on the 'Weighing of Interests"” (2013) 2 (emphasis added). See also Bolliger, supra, note 76, 335: "due to inherent worth, a living being must be able to lead a life typical of its species and to pursue individual objectives".

87 Art 3(a) TSchG. See also FSVO, supra, note 86, 2, 5-6; Bolliger, supra, note 76, 338-343.

88 Art 8(1) of the SR 814.91 Swiss Act on Non-Human Gene Technology of 21 March 2003 (Gentechnikgesetz).

89 FSVO, supra, note 86, 5-6.

90 Matti Hayry treats this line of thought as a dignity theory, but I do not consider it as such. The authors never meant it to be one - they instead focused on equality. Therefore, it does not fulfil the requirement of non-redundancy. See M Hayry, "Another Look at Dignity" (2004) 13 Cambridge Quarterly of Healthcare Ethics 7, 10; P Singer, Animal Liberation (The Bodley Head 2015) 8.
} 
It is also exactly these criteria that could deal with the technological developments mentioned above, most notably with the third category of cases which cannot be addressed through suffering arguments. The criteria used are thus capable of covering a broader range of situations than those currently used in EU and UK animal laws.

To be sure, the implementation of dignity in Swiss animal law may still suffer from some flaws. Swiss authors criticise it for, among other things, not including the right to life, ${ }^{91}$ as well as for its sentience threshold. The latter is claimed to be arbitrary and results, according to the argument, in the law suffering from an inner contradiction. ${ }^{92}$ Additionally, there are three further issues that are, in my opinion, relevant to dignity, but that do not seem to be readily available in the list of criteria in Swiss law that was set out above. These are the element of relationality; ${ }^{93}$ protection of animals after death; ${ }^{94}$ and protection of elements of a being other than only species membership, such as unique individuality (which may for example be relevant in the context of cloning ${ }^{95}$ ). A fuller investigation of these issues goes beyond the scope of this contribution. Suffice it to say for present purposes that, were the EU and UK legislators to implement animal dignity, such elements must not be overlooked. This is not to say that Swiss animal law provides us with a template that could be readily transplanted to another jurisdiction. It is submitted here that, although the proposed account of dignity seems to be in need of some further refinement, it very well illustrates how (at least some versions of) the notion of dignity could do a better job in dealing with the wave of technological developments discussed in this paper, compared to the notion of welfare that is currently used. Dignity seems to be a promising alternative.

\section{Conclusion}

Current EU and UK animal laws aim to prevent unnecessary suffering in animals. Proposals to recognise a broader category of animals as sentient and to update the Five Freedoms would most likely result in an improvement in animal welfare. However, their focus is on the subjective experience of animals only. This means the relevant laws

\footnotetext{
91 Bolliger, supra, note 76, 371-373; V Gerritsen, "Animal Welfare in Switzerland - Constitutional Aim, Social Commitment, And a Major Challenge" (2013) Global Journal of Animal Law 1, 10; Michel and Schneider Kayasseh, supra, note $85,15-16$.

92 Bolliger, supra, note 76, 369-370; H Röcklinsberg, The Ethics of Consumption: The Citizen, The Market, and The Law (Spinger 2013) 280.

93 This stands in contrast to a too individualistic view and features prominently in Foster's theory. J Herring, Caring and the Law (Hart 2013) also argues for a less individualistic approach of the law. For some more insight into how the element of relationality is relevant to one's identity, see C Foster and J Herring, Identity, Personhood and the Law (Springer 2017).

94 It is not clear whether Swiss law protects animals after death: Bolliger, supra, note 76, 366-368. For reasons I cannot further set out here, I consider such protection to be a crucial element of dignity.

95 In this context it may be referred to Arts 10-12 and 17-20 of the Swiss Animal Welfare Act. Furthermore, the issue of cloning animals for food production has been the subject of debate in the EU, although it is not clear to what extent concerns about the uniqueness of individual animals played a role. The main focus seems to have been put on animal welfare and environmental, health and economic risks. See previously in this journal, M Weimer, "The Regulatory Challenge of Animal Cloning for Food - The Risks of Risk Regulation in the European Union" (2010) 1(1) EJRR 31; J Corti Varela, "Coexistence of Genetically Modified, Conventional and Organic Products in the European Market: State of the Art Report" (2010) 1(1) EJRR 63; M Friant-Perrot and L Rihouey, "Failure of Conciliation Talks on the Use of Animal Cloning for Food: 'The Consumer's Right to Make Informed Food Choices'” (2011) 2(3) EJRR 414; I Carreño, "European Commission Proposes to Revise the EU's Legislative Framework on Novel Foods and Animal Cloning" (2014) 5(3) EJRR 362. See also Eurobarometer, "European's attitudes towards animal cloning", available at < ec. europa.eu/public_opinion/flash/fl_238_en.pdf > accessed 15 March 2019.
} 
would still not be able to adequately address those situations which many deem ethically wrong, but in which no suffering exists. Such problems already exist, and are likely to increase in number even further, due to the new technological innovations that were adumbrated above. Additionally, such innovations also further expose problems already present in existing areas of animal use, thereby highlighting the need for a broader basis of protection. Therefore, a new concept to justify animal laws and to determine their content is needed. Dignity might prove useful.

The preceding analysis gives rise to the following question: should dignity indeed be used to justify EU and UK animal laws and to determine their content? We have seen that the concept of dignity is capable of covering situations other than those in which welfare is an issue. Moreover, using dignity as the basis of EU and UK animal laws might make these law systems more internally consistent, as dignity is claimed to be the foundation for human rights laws as well. ${ }^{96}$ Nonetheless, there are further questions that need to be answered before one can give an answer to whether it is indeed desirable to use the concept of dignity as the basis of animal laws. First, one needs to decide what the most appropriate account of dignity is. This article proposes using Foster's account of dignity, and has shown how such an account could be made more concrete by drawing on the Swiss law on animals. Although it needs some further refinement, it seems to be a good starting point, as it is much more capable of dealing with the new wave of technological developments than the criteria that are currently used in the EU and UK laws. It should then be examined how this concept can be grafted into the law. Should it result, for example, in granting rights to animals, as has happened with human beings? Or would it be better to protect their dignity (or combine rights) with other forms of law, such as criminal laws or regulatory systems? Furthermore, it should be examined how such laws could be enforced (if at all). Is it possible to enforce animal dignity laws, or would other measures be more effective? One could think about allocating funding differently or about publicity campaigns.

Two further caveats are warranted. First, in arguing for a broader basis of animal laws, by no means do I intend to diminish the importance of animal suffering. It is prevalent on a massive scale, tremendously important for the quality of animals' lives, and, above all, features prominently in most (if not all) accounts of dignity. Second, implementing animal dignity into EU and UK laws might not be an easy task. On top of answering all the questions that were posed in the previous paragraph, there needs to be the political will to actually take this step. This will already seems to be largely absent when it comes to improving animal welfare, at the very least at EU level. ${ }^{97} \mathrm{~A}$ big hurdle would therefore have to be overcome. It is to be hoped that the legislatures (and indeed researchers) at the very least seriously discuss the option of using dignity, as well as the related questions that were posed in this contribution. Using dignity to justify animal laws presents great advantages, and should not be put aside lightly.

\footnotetext{
96 It will be recalled that this is predicated on the assumption that human dignity and animal dignity, as used in the law, function in the same way, and that incorporating animal dignity into the law raises questions as to whether consistency would require that animals be granted rights as well. See supra, note 67.

97 See Sowery, supra, note 10, 90-93.
} 